\title{
A RATIONAL ROMANTIC: THE IMPORTANCE OF BEING SYLVIA
}

\author{
Glen Cavaliero
}

It is well over sixty years since I first read Lolly Willowes, and I have loved and admired its author's writings ever since. Whereas contemporary academic criticism concentrates attention on Warner's politics, sexuality and feminism, what draws non-professional readers to her is her imaginative verve, so humorous and commonsensical, so ingenious and intelligent - in short, the sheer enjoyment her books provide. As with any genuine literary artist it is how she wrote that determines both the nature and quality of what she has to say. So what is it that makes her so good as a writer; why is her prose so readable?

In this connection a conversation with her uncle-bymarriage, Arthur Machen, is illuminating. In response to his thankful claim that for once he knew what to write 
about, she remarks that 'There is a sharp difference . . . in kind between that and knowing what one wants to write (Warner, 2012 p.216). Her awareness of that difference accounts for her peculiar excellence as a novelist: each book was written at the prompting of her imagination, for her own pleasure and without reference to any sense of self-importance or the forging of a literary career.

A relative still closer than Arthur Machen was also to influence her to good purpose. In a short book addressed to his Harrow schoolboy pupils, her father George Townsend Warner emphasises clarity of focus as a principal requirement in a writer:

Unless you have a clear picture in your mind you cannot make anyone else see it. Each touch of accurate detail makes your writer. see with your eyes, and that is what you want to do (italics original).

(G.T. Warner, 1915 p.101)

And that is precisely what his daughter does in the following account of a wagon ride along the lanes of nineteenth-century Essex:

A lantern hung from the shaft. When the wheels jolted over a rut or a stone it widened its swing and cast a sudden hoary being upon the trees that hung over the roadway. An owl hooted. A shooting star traversed the sky. A rabbit squealed in the hedge. Once they passed a gypsy cncampment in a clearing. The caravan was all sealed up, a boxful of strange slumbers, but the fire still blinked a drowsy ember or two, and lit up a battered corned-beef tin and an old broom. The dog barked straining at the rope which tethered him. Further on they passed a farm, and there the house-dog barked, and woke a flotilla of ducks on the pond. They swam up and down, quacking wildly, and the waters 
of the pond lolloped softly against the soft mud.

(Warner 1929 p.230)

This has been both seen and felt, details are reported for the most part in monosyllables, as a passenger might observe them. A battered corned-beef tin is the kind of object to linger in the memory; it also indicates the presence of that 'boxful of strange slumbers' - a typically compact Warner image. And how subtly the term 'housedog' suggests the contrasting security of a farm, while there is an airy mockery latent in the exuberance of 'flotilla', with its reductive echo in the 'lolloping' motions of the pond that brings the paragraph to a close. The journey is one in which a reader does not so much observe as share. It is this immersion in what the author sees before her as she writes which makes her work so satisfying: she does not intrude herself by way of commentary or by recording the passenger's reactions. She lets her readers alone and gets on with the job to her own - and thus to their - satisfaction. She is the kind of novelist whose imaginative powers are inseparable from her verbal methodology.

Recently I re-read yet again all seven of Warner's novels, this time in chronological order. It was an enthralling experience, and it made me realise that they were more purposeful and powerful than I had supposed. To start with, there is a perceptible difference in tone and narrative procedures between the first three books and the four that followed, a shift from a focus on individual consciousness to one on social context and conditioning. The early novels provide ironic slants on different kinds of romantic impulse. Lolly Willowes (1926), so delicate, witty, subtle, may be everything that characterises a mid-twenties exercise in the fanciful and unexpected, its very title a siren song, musical, alluring ... But the lady's real name was Laura, 'Lolly' a mere family diminutive, product of 
an infant's lisping prattle. As a title 'Laura Willowes' would suggest a more scrious affair, perhaps the account of an unsuccessfully rebellious victim of female domestic subordination, May Sinclair's Mary Olivier (1919), Radcliffe Hall's The Unlit Lamp (1924) and Winifred Holtby's The Crowded Street (1925) being previous examples. But Laura's rebellion is not that of a captive daughter but of a soul already free; so that once she has passed into Satan's kecping the retention of 'Lolly' in the novel's title sounds like a joke not only at the expense of unwary readers but one that rebounds in a family that has become 'carpeted with experience' (Warner, 1993 p.89): to them the withdrawal of the Lolly they think they know is inexplicable. Her quiet self-removal into the hidden life of great Mop admits her into "the secret country of her mind' (p.135). It is this assertion of her singleness that constitutes her contract with the Devil, the guardian of all outlaws and wild creatures. 'She had known where to turn ... She was a witch by vocation' (pp.175-176). An embracing of that call is signalled at the moment she discards her guidebook and throws it down a well (p. 128). This novel's oddity and pungent textures are attractive enough to lead an over-confident interpreter astray. One instance occurs during Laura's preparations for leaving her childhood home. She comes across

A bunch of dance programmes kept for the
sake of their little pencils, and all the little
pencils tangled into inextricable knots;
pieces of unfinished needlework, jeweller's
boxes, scraps cut out of the newspaper, and
unexplainable objects that could only be
remembrances of things she had forgotten. (pp.42-43)

The implicit poignance of such details is quite unsentimental, evocative of a particular aspect of domestic life. But in the following paragraph the mood intensifies. 
Thus busicd, she was withheld all day from her proper care. But at dusk she would go out of the house and pace up and down the nut alley at the foot of the garden. The cold airs that rose up from the ground spoke sadly to her of burial, the mossy paths were hushed and humble under her tread, and the smells of autumn condoled with her. However, the gardener, stamping out the ashes of his bonfire saw her pass to and fro, a slender figure moving sedately between the unmoving boughs. He alone of all the household had taken his master's death without exclamation. Death coming to the old was a harmless thought to him, but looking at Laura he sighed decply, as though he had planted her and now saw her dashed and broken by bad weather.

(p.43)

The sustained gracefulness of the prose ensures that the last two sentences are not reductive: the passage oscillates between romanticism and the matter-of-fact. The Tennysonian melancholy of Laura's mood is simultaneously sustained and held in check; assonance and alliteration promote the melodious exactitude of poetry. Simple words and careful phrasing serve the consolatory purpose of a steady metre; but the sentence beginning 'He alone' has a distancing effect. The statement of death's harmlessness proceeds to the ironic transfer to Brewer's practical but sensitive resort to metaphor. The passage exemplifies an clegant but realistic avoidance of exploitative emotionalism. Like all Warner's novels, Lolly Willowes is a book with bite.

The title of Mr Fortune's Maggot (1927) likewise is not quite what it secms, suggesting something humorous and quirky. But the story had its origin in a dream, one that was anything but quaint or charming:

A man stood on an ocean beach, wringing his hands in an intensity of despair. . . He 
was a missionary, he was middle-aged and a deprived character . . . he was on an island where he had made only one convert and at the moment I saw him he had realised that the convert was no convert at all.

(Warner, 1982 p.10)

Warner's response was to account for that predicament, and to uncover the source of his grief and to provide him with a second life - itself a missionary endeavour of her own. In doing so she was to write the most moving of her novels - indeed, the only one to warrant such a designation. (Its ending reduced even the sophisticated David Garnett to the point of tears.)

The opening is factual and sedate: "Though the Reverend Timothy Fortune had spent three years in the island of Fanua he had made but one convert'. This suggests the influence of T.F. Powys; but what follows is pure Sylvia Townsend Warner.

Some missionaries might have been galled by this state of things, or if too good to be galled, at least flustered; but Mr Fortune was a humble man of heart and he had the blessing which rests upon humility: an easygoing naturc. (Warner, 2000a p.1)

That casy-going nature is what makes him so readily at home in the tranquil paradise of Fanua: his desire to convert the perfectly contented islanders to his own beliefs and way of life is pre-empted by the boy Lueli's affectionate appropriation of himself. The outcome of his frustrated hopes is the loss of the very faith that prompted them, an obvious deflation that is seemingly endorsed by the term 'maggot'. But in this novel too there is an ironic gloss upon its title. The story may be affectionately amusing at the outset, but with its protagonist's loss of faith it ends on a note of utter desolation. Timothy realises that 
Because I loved (Lueli) so for what he was I could not spend a day without trying to alter him. How dreadful it is that because of our wills we cannot love anything without messing it about.

And yet that irony lurking in the story's title contradicts itself, for heartbreak over a failure in love is a nobler thing than the frustration of good intentions. And this change in mood results in the author being overtaken by the defeat of her own intentions as she is impelled impulsively to scrawl an admission opposite the final page, 'My poor Timothy, goodbye! I do not know what will become of you' (p.250)

So was it an irony at her own expense that she should try to find that out? She does so in 'The Salutation' (1932); but although clues are given as to the identity of the stranger who turns up at an isolated farm on the Argentinian pampas he remains nameless, a lone outsider whose prospects are a blank. A persistent theme in Warner's carly work is that of the choice between obedience to the dictates of an urge towards romantic adventure which has no apparently outlet, and an acceptance of a defeat that can end up in stagnation. It is a distinctively post-Christian dilemma.

That particular situation is not touched on in The True Heart, nor is there any irony where the title is concerned: this one is apposite enough. But Warner's re-working of the Eros and Psyche story, with its clear sighted eye on nineteenth-century class distinctions, is a case not of the myth inflating the story but of the story grounding the myth in actuality: its account of an orphaned charity girl's devotion to her mentally retarded lover has a sociological context, not spelled out but palpable: one not only sees the various country people but can almost touch and smell them too. This novel is well named, for in its down-toearth way it presents us with the sturdy innocence of one whose sights are set on her own true country of the mind. There is nothing sweet or quaint about Sukcy Bond, and David Garnett was right to object to the London scenes as 
demeaning her by submitting her to the kindly gaze of sophisticated aristocrats (Garnett, 1994 p.45), for in so doing Warner abandons what was, by her own account, the book's inspiration - the wild austere Essex marshland and the dignity of the people who inhabit it. The scene with Quecn Victoria is managed well enough, but it exhibits a kind of literary skill alien to its author's bent. As to the book's ending - "Joy!" she cried out, not knowing what she spoke" - it completes the mythological pattern appropriately, but whether Sukey herself survives the birth is left open to doubt (p.297). The True Heart is altogether tougher than on a first reading it may appear to be.

None the less it is not so tough as Summer Will Show (1936). This disconcerting novel marks a transfer from a concern with individuality to questions of politics, economics and women's place within society. It is a powerfully subversive book as it casts an equally cold eye on religious proprietics and on muddle-headed anarchism. The first section is formidable. Realistic, outspoken and blisteringly honest in its account of Sophia Willoughby's desire for a child to replace the two who have died from smallpox, it displays an unflinching attitude to the physical realities that condition emotional and idealistic states:

Which of them will die first? . . No one cver spoke truth in a sickroom. And they would both die, and since die they must, the sooner the better. This tinkling little manias, corrupting under her eyes, this snoring choking slug that lay couched so slyly under the lightning, these were not her children. Her own life had ceased in them, they were fever's children, not hers.

(Warner, 1987 p.66) 
The unrelenting honesty of this is breathtaking (some readers probably find it excessive and repellent). Yet when a surging cnergy of revolt against mid-nineteenth century social restrictions propels Sophia towards Paris and the feckless husband who alone can legally replace her loss, once again irony strikes. She finds herself setting up house with Frederick's discarded mistress and being outmanoeuvred by him and by her own implacably unflappable great-aunt (a character whom Warner admitted preferring above all others in the book). In her company the young Sophia

Had enjoyed an intimacy of confidence never known before, an intimacy lifting her from the discomfort of childhood, setting her among the ranks of grown women. How much plcasanter to be great-aunt Leocadie's Sophic than Mamma's Sophia... Mamma's Sophia was praised with faint condolence upon being such a good little girl with the old lady. The praises were accepted, and spat out privately as one spat out a mawkish lozenge; it would not do to disclose to the one woman that one liked the other quite as well.

(pp. 174-5)

The demure astringency of this is a shade misleading; satirical recollection has soon to be discarded. As the story ends Sophia finds herself alone, having been swept up into the revolution of 1848; her need for personal fulfilment is absorbed into a disillusioned political commitment. The last we see of her she is deep in the writings of Karl Marx. From now on Warner's novels are to switch their focus from individuals and their aspirations to the hazards attendant on living in community. It had been an underlying preoccupation of her previous work that was now to emerge into the open.

After the Death of Don Juan (1938), cven from this unpredictable novelist, is something of an oddity. For one thing, it discards the controlling authorial engine of a plot. 
Things simply happen. The first thirty pages or so are among the most balefully amusing that Warner ever wrotc: Dona Ana's ramshackle progress, complete with reluctant husband and long-suffering duenna, in order to announce Don Juan's supposed death to his elderly father, is a masterpiece of comic writing. But as the book proceeds, so savagery erupts. Dona Ana and her entourage trundle home again, an image of futility and the reader is left to contemplate the catastrophic effect of a flood upon a village community impotent beneath its feudal landlord's slovenly and uselessly well-meaning yoke. The satirical sub-text is there for the unravelling; the effect of the novel remains astringent. Although the Don Juan myth is deservedly debunked, the author's main concern is with the resilient resignation of the villagers in the face of exploitative incompetence, their own as well as that of their superiors. Warner's trenchant yet vivacious writing is itself a refutation of despondency, let alone despair. Her responsive empathy with Don Saturno and his tenants is a remarkable instance of how imaginatively to re-create the life of a remote community in a vanished age. It displays one of Warner's greatest achievements as a novelist, the gift for what might be called implied participation. She writes from inside her characters' lives, not as that of an observer, however sympathetic or intelligent. No wonder she admired her book.

Economics, in Don Juan a determining conrective to mere religiosity, is a controlling theme in The Corner That Held Them (1948). Novels about nunneries tend to record the efforts of their inhabitants to escape them; Warner chooses to describe the efforts of a community ti keep afloat in times of plague and social unrest, the later fourteenth century. Again, there is no plot as such, merely a chronicle of day to day occurrences, hazards, episcopal visitations. As in Don Jlian there is no single protagonist and any hankerings after self-fulfilment are invariably thwarted. It all sounds as flat as the Norfolk fenland in which the luckless inhabitants of Oby Priory pass their days. And yet, once again, Warner's resourceful 
command of language ensures that the book is stimulating even when recording hardships, boredom, smallmindedness and physical frustration. This is an historical novel quite free from the imposition of latter-day presuppositions. It is quite refreshing not to be invited to participate in moral and emotional self-questionings, and my guess is that for many of Warner's readers this book is an especial favourite.

But surcly it is The Flint Anchor (1954) which most of all distils her individuality as a novelist. Its account of the deleterious effects upon his family of a Victorian father's hyper-scrupulous conscience is sustained on the even tide of Warnerian prose as it bears a freight of comedy and satire to offset the prevailing tragic irony. Spatial divisions of the text are minimal, and there are no authorial directives, no sign-posting chapter headings; only towards the end do we receive the verdict upon what we have been shown, when John Barnard's youngest son gazes down at his father as the latter lies aslecp:

There he lay, the author (under God, as he would be the first to point out) of Wilberforce's being and of four other sons and five daughters, five of them dead, two self-exiled; and of untold mischief, fear and discouragement; a man who had meant no harm, who had done his best for his family, who had been faithful to his wife, and obedient to his God, and loyal to his country, and a model of commercial integrity, and who had spread around him a desert of mendacity and discomfort.

(Warner, 1997 pp.240-1)

The word that comes foremost to one's mind is 'justice': the balanced accumulation of fair-minded phrases, so plainly expressed, is the more telling because of all the verbal brilliance that has gone before. Emotional responses are left to the reader, an example of this reticence being the fact that the family's neglect of 
Barnard's dying wishes only becomes apparent when one turns back to the opening page. The subtlety and unsentimental compassion of The Flint Anchor makes Samuel Butler's handling of a similar theme in The Way of all Flesh (1903) seem crude.

Despite their unusual range of settings and subject matter Warner's seven novels are unmistakeably the product of an unfractured imagination, one that declines to subject itself to the corseting requirement of 'the well-made novel'. Each of her protagonists vanishes from sight; there are no dramatic resolutions, merely a fading away from the on-going processes of daily life. Laura removes herself from the clutches of her family and is last seen sitting alone in the woods at dusk; Timothy is exiled from Paradise to be, like Cain, a wanderer on the face of the earth; Sukey's story ends in a word of triumphant relicf that may at the same time be a death cry. As to Sophia, her personal aspirations are frustrated, while in what amounts to a very black comedy indeed, the people in Don Jtan are shown to be self-deluded, futile and incompetent. If the nuns of Oby are all of them helpless in the face of pre-conditioned circumstance, John Barnard ruins the lives of those he loves through his managerial obsession with doing the right thing. The message intellectually is bleak: no wonder the author was to withdraw into the heartless detachment of her Elfin kingdoms. There is not a shred of sentimentality about any of her books - which is precisely why the effect upon a sympathetic reader can be so buoyant and encouraging. That effect is furthered by the originality of her prose style. Here is the account of Julia Barnard's resignation at the onset of yet another family scene:

Her husband had many failings, and conscience had petrified most of them into 
faults, but unfortunately worldliness was not among them. There was no guest he would not have kept waiting, no dinner that he would not have let burn, if a moral fox broke covert. Mary had obviously spoken the truth, so Euphemia had been deceiving him. This must be looked into. (Warner, 1997 p.66-7)

The first sentence opens with an authorial statement of fact, but with that 'unfortunately' it modifies into a fusion of author and character - what Julia feels is interpreted and made explicit. The fusion is absolute where statement is concerned until that 'moral fox' breaks covert, absorbing simile into metaphor. The two following sentences are Barnard's own, the second of them being spoken to himself. Such weaving in and out of her pcople's thoughts and feelings is characteristic of her technique, and accounts for the peculiar sense of intimacy she can establish with her readers.

Surprising and appropriate similes are another factor in producing this result. Images are invariably precise, often culinary and occasionally shocking.

It was a movement of conscience the prioress had not expected, supposing that murder would lic as quictly under Dame Alice's self-assurance as a dead rat at the bottom of a cream-bowl.

(1993, p.197)

The appropriateness of the image is rendered the more persuasive through its ascription to the worldly prioress. Warner's similes can slide into metaphor, as when one reads of Dona Ana's ruminations, 'Back and forth her slow wits trudged over the field of her good memory' (1989, p. 49). Her writings abound in such felicities: despite all the exacting work she puts into them she clearly enjoys herself in doing so. The pleasure is infectious. 
In her early stories high spirits are much in evidence, witness the account of Mrs Molly who had

worn through two husbands, young Frederick Pottleby and Matthew Molly. She had worn them in proper order, one after the other, but a flavour of bigamy hung about her, because, while the younger folk of Lovebourne Bishop called her Mrs Molly. Her contemporaries gencrally referred to her as Mrs Fred. She was a lean, sallow, November-looking woman, with a wall eye, and she wore such an unfailing series of rather dirty men's caps that she might have supposed that she had enjoyed as many husbands as the woman of Samaria. ('This Our Brother' in Warner $2000 \mathrm{~b}$. p.15!-2)

The cool vivacity of this, the odd, illuminating phrascology combine a sophisticated wit with an eye for detail; it puts the character on display. But compare this description with that of Dame Louisa Stapledon engaged in copying out one of the psalms of David.

The sunlight fell on the page and lit her scarred face and the few light eyclashes stuck in her swollen eyclids. Her hand, moving in the sunlight, displayed all its defects, the toad-skin, the misshapen nails, the look of being ingrained with dirt which overlies unwholesome blood. Her attitude and expression showed a slow-burning thrifty happiness, and she resembled a virtuous wolf. $\quad(1993$, p.186)

There is a sense of personal participation here: it is as though the author is portraying her own delight in composition. 
A more subtle attention to detail is introduced almost casually when a beggar woman relucts at returning to Oby where she has quarrelled with the nuns.

But after her outburst . . . at the best she would come off with some old rags, a clipped shilling, and some more of that soup.

(p.255)

Not just soup - that soup. We are inside the woman's mind, not being informed by an omniscient author of its contents, and have a pretty good notion of what that soup was like.

Elsewhere in the same novel one comes across a very different use of detail. An English rhyming epic is being described, evoking the meanderings of such 'unadventurous adventures'.

Even when Mamillion came on Christ in the depth of a yew forest, bewailing, and hiding his face in the bitter yew boughs, no conversation or judgement came of it; Mamillion only gazed, and pitied, and rode on. (p.119)

The placing of those commas serves to deepen the breathtaking nature of such a casual reference: an aspect of Christ's sufferings is glimpsed, only to be thrown away as the manuscript is discarded. The vision haunts the mind; eeric and unnerving, it is another example of how sympathetic Warner's imagination could be, enabling her to engage with the implications of a religion in which she herself did not believe. (It also resembles her dream of the hapless missionary who was to become Timothy Fortune.) 
Such powerful moments in Sylvia Townsend Warner's work are legion; yet for certain anxious readers the question remains: is she to be considered a marginal literary figure or an important one? One wonders why (unless for purposes of drawing up examination syllabuses) the question should arise. Such concepts as 'major' or 'significant' when applied to imaginative literary works are spatial metaphors applicable to place or time; but works of this kind provide a fusion between the two, and it is their quality of livingness which unites writer and reader. In Samuel Johnson's words, 'The only end of writing is to enable readers better to enjoy life, or better to endure it' (Johnson, 2000 p.536). Warner's demonstrations of the imaginative rewards of paying close attention to the material world, and delight in the responses to it of its various inhabitants, could seem to satisfy those requirements perfectly.

Because she digs down to the roots of her subjects, she may be called a radical novelist, being concerned with her material for its own sake and not with her own responses to it. Her intensification of the physical is such as to suggest a kind of materialistic spirituality or romantic rationalism. Self-sufficient in her dedication to, as her Diary records, getting things right, she was wary of being 'more interested in the story than in the telling' and of 'trying to give it life instead of giving it art' (Warner, 1994 p.211). In the upshot, her interests and her endeavours were to be fused in an achievement which raises readability to a level that assures her a place alongside those writers of fiction to whose work one returns compulsively in quest of both mental stimulus and imaginative enjoyment.

Above all she is an author who heartens one and who can make one laugh out loud. Never writing at her readers nor, with a knowing cyc, sceking thcir collusion, she is entirely absorbed in her subject matter. Her domestic metaphors, her interest in daily practicalities, render her work immediatcly approachable. Directing one's attention 
to the pungent qualities of surfaces, she sharpens her readers' perceptions and elevates the spirit. Having had my own spirits lifted out of the mire by yet another of her short stories (alas, I do not now remember which) I nerved myself up to write and thank her for the years of delight and solace her work had given me. The reply, in that incomparably elegant and swirling script of hers, was both appreciative and to the point. 'You praise me for exactly the qualities I try to achieve - what in cookery is called "a light pastry hand". After such complimentary incisiveness any further praise of her achievement would be, as Sylvia Townsend Warner might herself have put it, to over-egg the cake.

\section{WORKS CITED}

GARNETT, R (Ed.) (1994) Sylvia and David. The Townsend Warner/Garnet Letters. Sinclair-Stevenson.

HALL, R. (1924) The Unlit Lamp. London: Cassell.

HOLTBY, W. The Crowded Street. London: Bodley Head.

JOHNSON, S. (2000) The Major Works, Review of [Soame Jenyns] A Free Enquiry into the Origin and Nature of Evil (1757). Oxford University Press. pp.522 543.

SINCLAIR, M. (1919) Mary Olivier. New York: Macmillan.

WARNER, G.T. (1915) On the Writing of English. London: Blackic.

WARNER, S.T. (1929) The True Heart. London: Chatto \& Windus.

(1982) Letters Ed. William Maxwell. London:

Chatto \& Windus.

(1987) Summer Will Show. London: Virago.

(1988) The Corner That Held Them. London:

Virago.

(1989) After the Death of Don Juan. London: Virago.

(1993) Lolly Willowes, or The Loving Huntsman. London:

Virago. 
(1994) The Diaries of Sylvia Townsend Warner.

Ed. Claire Harman. London: Chatto \& Windus.

(1997) The Flint Anchor. London: Virago. (2000a) Mr Fortune's Maggot. London: Virago. (2000b) The Salutation. Horam: Tartarus Press. (2012) With the Hunted. Selected Writings, Ed. Peter Tolhurst. Norwich: Black Dog Books. 